\title{
PSYCHIC DEVELOPMENT OF THE CHILD: PSYCHOLOGICAL, HEREDITARY, FACTORS, ENVIRONMENT
}

\author{
Pascariu Constantin Cătălin ${ }^{1}$, Oprea Ionuț Mihai ${ }^{2}$ \\ ${ }^{1} \mathrm{PhD}$, Lect. University of Oradea, Romania, costi_pascariu@yahoo.com \\ ${ }^{2} \mathrm{PhD}$, Lect. University of Oradea, Romania, oprea_ionut_mihai@yahoo.com
}

\begin{abstract}
Regarding the human development we can say that it represents a continuous evolution, from birth to adulthood. This involves physical processes (human body) and mental ones (thinking, memory etc.). In time, there were different theories that tried to explain this phenomenon. Thus, the theory of Progressive Development, shows that the only absent elements from the children's reasoning are those that they haven't come across or they haven't experienced. Some of them show that the children's development is not that predictable, but, even more; it goes through certain highly delimited stages. Each of these stages follows the previous one and is characterized by specific skills and abilities. This development based on stages is known under the name of the Theory of Stages or the Theory of Discontinuity. Piaget, Erikson and Kohlberg are some of the promoters of this of human development based on stages. What is the human being? This is another difficult question. Though, taking into consideration the elements that surround us, we can say that the human being is the result of the inheritance, of the environment and of education. These elements have an impact on the human being, thus, the will and the autonomy are both influenced by them. This article is the theoretical representation of a study that is to be completed by a practical research and a well elaborated methodology and has as a main objective, the influence of the environment, of the hereditary and psychological factors upon the mental development of the child. We wish to check the assumption starting with the development of the mental factors, the children develop in different ways, according to the external environment and to the hereditary factors, and so we wish to check it through a questionnaire about the way in which the teenagers adapt to the social life. The research question we will try to answer is "Can the environment and hereditary factors influence the child's mental development?" Education is an important factor in human mental development, so we address in this article the cause-effect method as a way to express the relationship between environment and heredity in the mental development of the child.
\end{abstract}

Keywords: child, development, heredity, society.

\section{INTRODUCTION}

What is man? A sum of all influences? The result of heredity, of the environment, of education? How great are the influences received in comparison with the will and autonomy of man and how much are they worth in the formation of the individual? Is man free to be what he wants or is he constrained by certain forces that he cannot control? T. Pop tells us that heredity does not transmit traits, characters formed from parents to children, how property is transmitted from one to another, but through it, children receive from parents dispositions, inclinations, good and bad influences, mostly good or mostly bad.

On the other hand, regarding the environment, Jacque Fresco tells us that all human beings are influenced by the environment. These influences fit so well into our habits, thoughts, feelings, and perspectives that we really believe what we are told. Learned behavior is part of human nature.

No other species has adapted to the natural environment by transforming it as man has done and is doing, more and more rapidly and radically. No other species has doubled and changed its existential framework through culture and civilization, thus placing itself, at the same time, in a double adaptive game: nature and 
culture. In the case of our species, theorists of evolutionary psychology, one of the most recent branches of the contemporary psychology, speak of a "double heredity" - that transmitted through genes and that transmitted through memes (C. Cucoș, 2009).

The concept of development refers to the totality of successive changes (physical, cognitive, social, emotional) that an individual goes through throughout his life (respectively from the moment of his conception until the moment of death). Development is the result of adaptive processes; some of these processes are cumulative and continuous, others innovative and discontinuous (Mih, V, 2018).

It has long been considered that human development follows a continuous evolution from childhood to adulthood, and children think similarly to adults. At the same time, there is a belief that the only elements absent from children's thinking are those that have not been the subject of their experience or education. Such a perspective of continuous progress crossed by a subject is known as the theory of the progressive development. Subsequent theories have shown, however, that the developmental trajectory of children does not have such a predictive evolution, but rather a series of well-defined stages or phases of development. Each stage succeeds the previous one and is characterized by specific skills and acquisitions. Development in stages is known as the theory of the phases, or the theory of discontinuity. Piaget, Erikson and Kohlberg are some of the promoters of such a staged conceptualization of human development (Mih, V, 2018).

\section{ENVIRONMENT}

The environment is the totality of the natural and social influences, physical and spiritual, direct and indirect, organized and unorganized, voluntary and involuntary, which is the framework in which the human being is born, lives and develops (F. Golu, 2015). The environment possesses properties of density (richness or poverty of the demanding conditions), of intensity (very intense, medium or weak demands); especially highintensity overloads can affect the mental development. The third feature of the environment is that of the pace of change and development. There are adaptability limits for all cases in this regard. In humans, these limits are more complex and obviously specific (S. Briceag, 2017).

Therefore, environmental conditions are very varied and act on all dimensions of the human being. Geographical conditions and, in particular the climatic conditions, influence the body's metabolism and other functions. The climatic regime is important for general physical development and brain activity and ultimately for the mental evolution (F. Golu, 2015).

The most important influences are (F. Golu, 2015):

a. Socio-economic, regarding the material conditions of existence;

b. Socio-professional, represented by the statutes and professional roles of those around;

c. Socio-cultural, regarding the means of training, the access to culture and the level of schooling and preparation of those around;

d. Socio-affective, referring to the frequency and quality of the connections with others and to the affective climate that generates different processes and affective states and contributes to the formation of attitudes and personality traits.

From systematization requirements we can speak of the physical bioclimatic environment, of the socialhistorical environment (economic, political-cultural) as well as of the psychological environment. There is a close interdependence between them, the social-historical environment having the largest weight in human development. It is considered that the bioclimatic environment exerts its influence on human in terms of biological maturation and body growth. The bioclimatic environment influences some human occupations, the way of life through the vegetal and animal wealth that it offers, also through water, ores, raw materials, which determine the economic characteristics of the social life (S. Briceag, 2017).

For most children between the ages of zero and three, the family environment is what stimulates them and ensures their mental development. The family is a tutelary group that exercises multiple influences. It creates conditions for obtaining a social identity (name, citizenship, etc.), provides protection, security, comfort, conditions of growth, education, satisfaction of desires, allows the establishment of civilized behaviors, mastering the basic rules of conduct, hygiene, nutrition. For some children between one and three years old, the nursery environment can also intervene. Furthermore, the kindergarten environment, the primary school, the middle school, the high school, the secondary school, the university, the postgraduate school come into action. The role of the school has greatly increased within social life. The school has intensified and further accelerates the transmission of the heritage and socio-cultural and scientific values from generation to generation. It organizes and intensifies the process of training and education, constituting one of the social 
institutions that creates and regulates more and more the equal opportunities of the youth. There are school cadres who exert social, cultural, scientific, civilizing, formative and psychological influences. The school is the projection of society into the future. Future long-term social development depends on its quality. Beyond the school years, the workplace begins to act. Then the rural or urban community, the area of the country and the continent where everyone's life takes place. Most of the time, there are convergence relations between the influences exerted by these environments and this fact supports the psychic development favorably. But there can also be divergent relationships, and, in this case, development may be delayed and may be more difficult (A. Munteanu, 2006).

The environment is the first great "transformer" that acts on the hereditary fund of each, activates it and makes it contribute to the mental development. It is a socializing factor because in the middle of the others everyone learns to communicate, to cooperate and to collaborate with those around them. It prepares everyone to have access to the culture of the community in which they were born. It generates values and appreciative criteria that become the main factors of the orientation, development of the individual. The environment can exert both positive and negative influences that must be counteracted by the third fundamental factor, education (F. Golu, 2015).

\section{HEREDITY}

Heredity is the biological process through which the transmission of morphophysiological characteristics from ascendants to descendants is ensured. Equally, by heredity we mean the set of characteristics transmitted through specific biological mechanisms - from ascendants to descendants. The biological discipline that studies the heredity and variability of the organisms, the mechanisms of recording/fattening, conservation and transmission of the genetic data from one generation to another is called genetics (K. Barth, 2019). Hereditary traits are controlled by genes, and the set of genes in an organism's genome is called a genotype. The set of all observable characteristics in the structure and behavior of an organism is called a phenotype. These characteristics are the result of interactions between the genotype and the environment. As a result, many aspects of an organism's phenotype are not hereditary, such as tanned skin. The tanned color of the skin is not passed on to descendants. However, some people tan more easily than others due to the differences in genotypes. An example in this sense is represented by albino people, who do not tan at all and have very sensitive skin to sunlight (ibidem).

The foundations of human development are biological, interactive and environmental. By relating the biological theories to evolutionary theory focusing on child development, Piaget, Vygotsky, Jhon Bolwby and others created currents of developmentalist thinking (A. Muntean 2006).

A crucial moment in the evolution of conceptions about the developmental psychology was the publication of Charles Darwin's book, The Origin of Species in 1859. The essentials of the theory are that all populations of different species tend to produce more individuals than they can survive, better adapted individuals will pass on genetic benefits to their descendants. Research in the field of genetics has recently been completed by an attempt to draw a map of the human genome. It has thus been confirmed that the number of genes is higher as organisms are more complex. Man has 30,000 genes, while the fly has 10,000 and the mouse has 15,000 . The surprise, however, was the inventory of a large number of "mutant" genes, the largest in all life forms ("mutant" genes being considered genes that allow formation/structuring of functions/behaviors in the process of adapting the individual to the environment) (F. Golu 2015).

One of the great questions that developmental psychology tries to answer is the relationship between the innate and the learned, in the evolution of the individual. There are theories that support the primacy of heredity over the forces of environmental factors in human development but also the reverse: at birth the human being is tabula rasa and becomes what the environment determines it to be. Exaggerating the importance of a certain side (innate or learned) can be dangerous. Ineist theories can lead to the dangerous concept of superior races, and theories that relate everything on the environment ignore the uniqueness of each individual. (A. Muntean 2006).

Man does not inherit by heredity psychic processes, functionally structured capacities, but the predisposition to form and to build them. Genetically is transmitted - for example - the ability to learn but not the content of what our ancestors once learned. Finally, a synthetic vision of human development is recommended "development is the process of forming new sets of processes, attributes and psychic dimensions and continuous restructuring of them, a process that: relies on the field of heredity, extracts its contents from the data provided by the socio-cultural environment, is guided by education, takes place in the context of their own learning activity, being driven by motivation and having as a mechanism the transition from outside to inside ". The interaction heredity-environment represents a final result, in terms of behavior, of the human 
development, an inextricable link (F. Golu 2015, pp. 20-25).

\section{EDUCATION, THE MAIN FACTOR OF HUMAN PSYCHIC DEVELOPMENT}

Education is the third fundamental factor of the mental development, which most researchers consider the most important (E. Bonchis, 2004).

Education is the set of actions and activities that integrate the human being as an active factor, is carried out systematically, unitary, organized, having a content with necessity defined by society, using appropriate procedures, methods, means, and being driven by special competent skilled factors (ibidem).

Therefore, the educational actions are not exercised at random and are not added from outside the subject, but they are carried out only with its participation. Exercising for a long time on everyone, education achieves a fundamental formative function oriented according to the requirements of society and adapted to the particularities of children and young people. To the extent that it is organized and conducted in accordance with the data of the sciences about man, it becomes a constructive process that tends to fully realize the hereditary availabilities of each (ibidem).

Concluding on the contribution of education, we must remember the following roles played by it (E. Bonchis, 2004):

- Is the second factor that transforms the hereditary potential into components of the psychic life;

- Directs convergently with its goals even the environmental influences;

- Forms the higher mechanisms of the human psyche. For example, it develops thinking to the highest share;

- Designs the mental development and ensures the conditions for carrying out these plans;

- Ensures the full mental development of man;

- Stimulates mental development by creating optimal gaps between requirements and possibilities and by appropriate support in order to overcome these inconsistencies.

- To some extent education accelerates mental development.

\section{CAUSE EFFECT}

If they live in criticism and harassment, children learn to condemn;

If they live in hostility, children learn to be aggressive;

If they live in fear, children learn to be anxious;

If they live surrounded by mercy, children learn self-pity;

If they live surrounded by ridicule, children learn to be shy;

If they live in jealousy, children learn to feel envy;

If they live in shame, children learn to feel guilty;

If they live in encouragement, children learn to be confident;

If they live in tolerance, children learn patience;

If they live in praise, children learn to appreciate;

If they live in acceptance, children learn to love;

If they live in approval, children learn to please themselves;

If they live surrounded by recognition, children learn that it is good to have a goal;

If they live by sharing with others, children learn to be generous;

If they live honestly, children learn respect for the truth;

If they live in righteousness, children learn to be righteous;

If they live safely, children learn to trust themselves and others;

If they live in friendship, children learn that it is pleasant to live in the world. 


\section{FACTORS OF MENTAL DEVELOPMENT-EDUCATIONAL FACTORS}

As the scientific knowledge in psychology has evolved, the psychology of development has become a distinct branch of general psychology, a branch that has developed its own body of theories and explanatory models. From most of the descriptive-explanatory models of human psychic development do not lack references to conditional or determining factors, stages, psychogenetic landmarks of the appreciation of the developmental process. By factors of psychic development are meant those constant, profound and essential influences which are exerted on the individual and produce the transformations specific to development. The development of the human body takes place on several levels, but nevertheless is unitary, determining the evolution of the individual, as a whole. Thus, we can talk about (F. Golu, 2010, p. 18):

- Physical development, which brings together changes in length, weight; changes in the structure and function of the brain, heart and other internal organs; changes in the skeleton and muscles, which affect the motor skills. These changes exert a major influence on both the intellect and the personality;

- Cognitive development, which includes changes that occur in perception, learning, memory, reasoning, language. These aspects of the intellectual development are related to the motor and emotional development;

- Psychosocial development, which includes changes that occur in the personality, emotions, relationships of the individual with others. At any age, the way in which one's own person is conceptualized and evaluated influences not only the cognitive performances, but also the biological functioning of the body.

The major object of the human development is the discovery and understanding of the processes and interactions that occur over the ages. It is a continuous phenomenon, permanently influenced by the native and acquisition characteristics and our experiences. Developmental psychology studies how a body changes from quantitatively and qualitatively point of view, during life. Synthetically, in the literature are mentioned as factors of mental development: heredity, environment, education. The heredity-environment relationship in influencing psychic development has been the subject of disputes whose conciliation is not fully guaranteed even today. Extremist, reductionist tendencies (of over or underestimation of one of the two factors) are still present and active in both the theory and practice of the education today (Barth, K., Ciobanu, N.R., 2017).

Nativism and constructivism in explaining the development of the psychic structures (in theory) and the practices of educators, demonstrate that there is a tendency to overestimate or underestimate either the influence of heredity or the influence of the environment on psychic development. The human psyche is the result of the interdependence between the natural factors (heredity) and the social ones (environment and education) (E. Bonchis, 2004).

\section{THE RELATIONSHIP BETWEEN HEREDITY AND THE ENVIRONMENT}

In the Romanian psycho-pedagogical literature (A. Munteanu 2006), heredity, environment and education are discussed as factors of psycho-individual development, while Western literature deals with the naturenurture relationship ( the Anglo-Saxon) or hérédité-milieu/environment (the French). Depending on the era and the context of the analysis, the operationalization of this relationship was expressed differently: maturation-learning, innate-acquired, ineism-empiricism, nativism-constructivism/cultural relativism. The signaling of these nuances defers the observation that, in fact, the categorical delimitations have only didactic reasons. Heredity, as a general property of the living world, is a characteristic of the natural environment, just as education necessarily presupposes a human social environment in the absence of which it could not exist. Heredity is the fundamental property of the living matter to transmit, from one generation to another, messages of specificity in the form of the genetic code. These are traits that define by turn both the human species (which differentiates it from other beings, such as bipedal position, rationality, consciousness, etc.), properties of the racial group (such as skin color, medium size, etc.) and also individual peculiarities (eye color, temperamental predisposition, etc.) (C. Cucoș, 2009, pp. 153-154).

On the other hand, the environment, as a factor of human development is made up of all the elements with which the individual interacts directly or indirectly during his development. In terms of content, the influences of the environment cover a multitude of plans: from the geonatural (climate, relief) to the social (family, playgroup), indispensable for a human-type ontogeny. The action of the environment "can be immediate (food, climate) or mediated, through the forms of human adaptation it generates (dominant activities, type of social organization, standard of living, degree of culture and civilization, etc.)" (C. Cucoș, 2009, p. 160).

A very interesting thing observed in the Principles of New Genetics (Benga, 2002, p. 27) is the fact that "Genes are variable" - can change both their behavior and structure due to interaction with other genes or 
due to environmental conditions. So, genes are not fixed, well-defined, context-independent entities. Hence, the idea of adaptive modifiability of genes, which can even be passed on to future generations) (C. Cucoș, 2009, p. 157).

From the perspective of the psycho-individual development issue, it is extremely important to emphasize that the emphasis is not on the simple presence or absence of the environmental factors, but on the extent, manner and resonance of the interaction between those factors and the human individual. An environmental factor which is present, but indifferent to the human subject, is inert from the perspective of development. The condition of development is for that factor to act on the individual, who in turn to react, which creates interaction.

In short and on the clearer meaning of things; while heredity deals with the transmission of information from the inside out, the individual being not responsible at all for the genetic baggage with which he is born, the environment deals with the transmission of information from the outside inwards; the individual being influenced by what he sees, so that the environment favors or not certain genetic predispositions activating to the individual a certain behavior that is already implemented in the received genes. The only condition is given by the importance that the individual attaches to the things given by the environment. As the interest in the environment grows, the chance of activating the genetic potential is greater and vice versa.

\section{REFERENCE LIST}

Barth, K.M., (2019), The role of multicultural projects in the development of the personality of children with special educational needs, in "The role of intercultural communication in adapting ethnic groups to the European Union Social Space", edt. K.M Barth, M. Brie, D. Dărăbăneanu, I. Polgar, Lambert Academic Publishing, Ltd., pp. 307-315.

Barth, K., Ciobanu, N.R., (2017), Mass media influence upon personality development of children, in "Education and Applied Didactics", Vol. I, Issue 1, 2017, Publishing House of University of Oradea, pp. 7-25.

Bonchis, E., (2004), Child Psychology, University of Oradea Publishing House.

Briceag, S. (2017). The psychology of ages. University Publishing House "ALECU RUSSO", Balți.

Cucoș, C., (2009), Psychopedagogy for final exams and teaching degrees, Polirom Publishing House, lași.

Golu, F. (2015). Handbook of developmental psychology: a psychodynamic approach, Polirom Publishing House, lasi.

Mih, V., (2018), Psychology of education, Publishing House of the Cognitive Association of Romania, ClujNapoca.

Muntean, A. (2006). Psychology of human development, Polirom Publishing House, lasi. 